\title{
Adenoid Cystic Carcinoma of the Breast: A Rare Histopathology- Good Prognosis
}

\section{Meme Adenoid Kistik Karsinomlu Olgu: Nadir Histopatoloji- İyi Prognoz}

\author{
Onur Esbah ${ }^{1}$, Ahmet Siyar Ekinci ${ }^{1}$, Emine Benzer ${ }^{2}$, Tahsin Ozatli ${ }^{1}$, Berna Oksuzoglu ${ }^{1}$ \\ ${ }^{1}$ Dr. A. Y. Ankara Oncology Training And Research Hospital, Medical Oncology Clinic, Ankara, Turkey \\ ${ }^{2}$ Dr. A. Y. Ankara Oncology Training And Research Hospital, Pathology Clinic, Ankara, Turkey
}

\section{ÖZET}

Giriş: Adenoid kistik karsinom (AKK), memenin nadir görülen neoplazmlarındandır. Tüm meme karsinomlarının \%0.1'ini oluşturmaktadır. AKK'lar memede izlenen diğer histolojik alt tiplerine göre çok iyi prognoza sahiptirler. Uzak metastaz ve lenf nodu tutulumu çok nadirdir. Sıklıkla östrojen reseptörü (ER), progesteron reptörü (PR) ve c-erbB2 durumu negatif olarak tespit edilmektedir.

Olgu: Kırksekiz yaşında premenapozal kadın hasta sol memede ele gelen kitle nedeniyle doktora başvurmuş. Hastaya memedeki lezyon için tru-cut biyopsi uyguland1. Biyopsi sonucunun AKK olarak gelmesi üzerine hastaya modifiye radikal mastektomi operasyonu uygulandı. Operasyon materyalinin patolojik incelemesi orta derecede diferansiye AKK ile uyumlu olarak tespit edildi. Tümör boyutu $4.8 \mathrm{~cm}$ ve aksiller diseksiyon sonucu 48 lenf nodu negatif olarak tespit edildi. Tümörün immünohistokimyasal özellikleri triple negatif (ER, PR ve cerbB2) olarak değerlendirildi.

Sonuç: AKK'ler çoğunlukla ER(-), PR(-) ve c-erbB2 (-) durumu ile ender görülen meme karsinomlarıdır. AKK'ler nadir görülen meme karsinomları olduğundan ve yeterli klinik çalışma bulunmadığından tedavi opsiyonları sinırlidir.

Anahtar Kelimeler: Meme neoplazm; adenoid kistik karsinom; iyi prognoz

\begin{abstract}
Background: Adenoid cystic carcinoma (ACC), one of the rarest neoplasia of the breast, constitutes $0.1 \%$ of all breast carcinomas. The prognosis of ACC is very good compared to other histological subtypes of breast carcinoma. Lymph node involvement and distant metastasis are very infrequent. Estrogen receptor (ER), progesterone receptor (PR) and c-erbB2 (also known as HER-2/neu) are typically negative.

Case Report: A fourty eight year-old premenauposal women was admitted to hospital with a mass on the upper outer quadrant of her left breast. Since the result of through-cut biopsy of this suspicious lesion was consistent with adenoid cystic carcinoma, modified radical mastectomy with axillary lymph node excision was applied. Pathological examination revealed a moderately differantiated adenoid cystic carcinoma of the breast. The size of invasive tumor component was $4.8 \mathrm{~cm}$ in its greatest dimension. Immunohistochemical analysis was consistent with triple negative phenotype (ER,PR and c-erbB2 negative).

Conclusion: ACC is a rare type of human breast carcinoma with ER, PR and c-erbB2 negative phenotype. They usually show an excellent prognosis however there is no well defined treatment options for ACC since the rarity of clinical studies in such kind of unusual histological subtypes of breast carcinomas.
\end{abstract}

Key words: Breast neoplasms; Carcinoma; Adenoid cystic; Good prognosis

\section{Background}

Adenoid cystic carcinoma (ACC), one of the rarest neoplasia of the breast, constitutes $0.1 \%$ of all breast carcinomas (1). The prognosis of ACC is very good compared to other histological subtypes of breast carcinoma. ACC of the breast is commonly seen in perimenapausal patients. The median age at the time of diagnosis is usually at the $5^{\text {th }}$ and $6^{\text {th }}$ decades (2). Although mostly located subareolar area of the breast, nipple and/or skin changes are rarely encountered. Lymph node involvement and distant metastasis are very infrequent (3). Estrogen receptor (ER), progesterone receptor (PR) and c-erbB2 (also known as HER-2/neu) are typically negative.

\section{Case Report}

A fourty eight year-old premenauposal woman 
was admitted to the hospital with a mass on the upper outer quadrant of her left breast in May 2011. On physical examination there was a non-tender mobile $2 \times 2 \mathrm{~cm}$ mass without nipple or skin changes, and axillary lymph nodes were not palpable. Mammography and breast ultrasonography revealed a $2 \times 3 \mathrm{~cm}$ suspicious mass consistent with malignant phenotype. Tru-cut biopsy of the lesion was reported to be ACC. Modified radical mastectomy (MRM) and axillary dissection was planned thereafter as curative surgery. Pathological examination of the operation material was reported as moderately differantiated ACC of the breast (fig. 1). The greatest dimension of the invasive tumour was $4.8 \mathrm{~cm}$ with 48 reactive lymph nodes. Immunohistochemical (IHC) analysis of the tumor was consistent with triple negative (ER, PR and c-erbB2 negative) phenotype.

Tumor was pathologically staged as T2NOM0, stage IIA and adjuvant antracycline based chemotherapy was applied. The patient

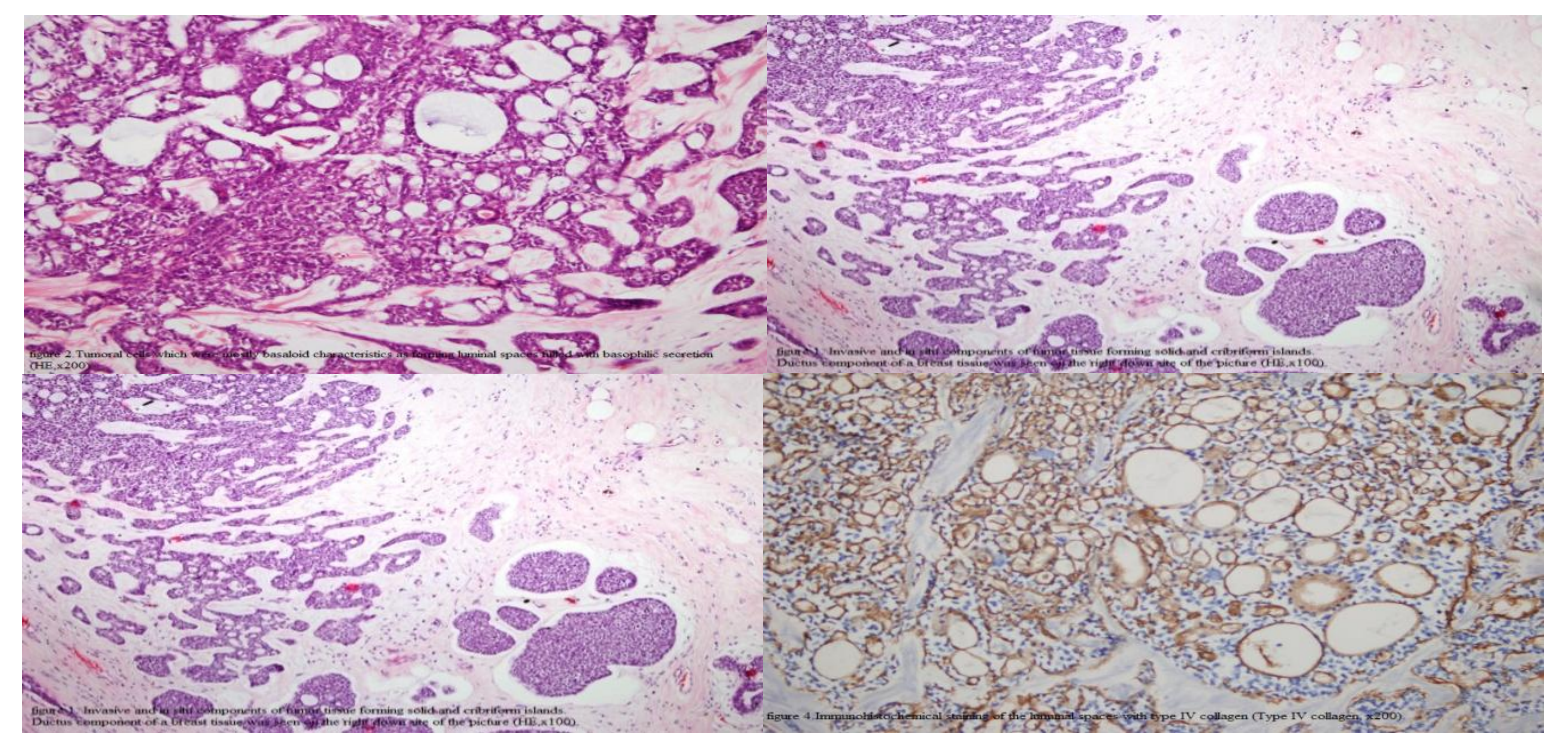

Figure 1: Invasive and in situ components of tumoral tissue forming solid and cribriform islands (HEx 100).

Figure 2: Tumoral cells which mostly had basoloid characteristics forming luminal spaces filled with basaloid secretion (HEx200) Figure 3: Immunohistochemical staining with high molecular weight cytokeratin (cytokeratin 14, IHC CK 14x200) Figure 4: Immunohistochemical staining of luminal spaces with type IV collagen, Type IV collagen x 200).

is disease free from a duration of 30 months follow-up period.

\section{Discussion}

ACC is a rare neoplasia of the breast (1). ACC histopathologically resembles salivary gland pattern and formerly called as 'cylindroma' by Billroth (4). Mc Clenethan et al. evaluated 27.970 breast carcinoma patients diagnosed between 1960 and 2000 and reported 22 ACC histopathologically (3).

ACC cases are usually defined in perimenapausal women in their 5th to 6th decades however ACC in men was very rarely reported in the literature (5). ACC is mostly

observed in the subareolar site of breast. Nipple and skin changes are seldomly involved (5). In the presented case however, the tumor was in the upper outer quadrant. Besides, nipple or skin changes were also not a feature of this case.

Although fine needle biopsy was enough to recommend for the diagnosis, in the presented case, a tru-cut biopsy was applied. In the literature, the average size of invasive tumor of ACC patients was reported to be $2 \mathrm{~cm}$ but varied greately from $0.2 \mathrm{~cm}$ to $12 \mathrm{~cm}$ (2). In the presented case, the tumor size was 4.8 $\mathrm{cm}$.

ACC cases are mostly presented with the IHC phenotype of triple negative or basal like breast cancer as ER, PR and c-erbB2 negative (6). Pathological criteria of ACC involves biphasic cellular pattern consists of basaloid myoepithelial cells together with ductal epithelial cells (7). In the presented case, a triple negative phenotype was detected. ACC of the breast was reported to have an excellent prognosis because of the rare 
tendency of lymph node involvement and distant metastasis. If distant metastasis occurs, it usually appears before axillary involvement (3). The most common site of distant metastasis are the lungs. Arpino et al. found only four cases of lymph node metastasis in a review of 182 cases and 14 distant metastasis without lymph node involvement (2). Since the rarity of lymph node metastasis, axillary dissection is usually not recommended. Local excision, simple mastectomy or MRM are the curative treatments of choice.

Ro et al. recomended local excision without axillary disection for grade I tumors (without solid components in the tumor), simple mastectomy for grade II tumors $(<30 \%$ solid components in the tumor) and MRM for grade III tumors ( $>30 \%$ solid components in the tumor) (8), but also radiotherapy for cases treated by local excision and simple mastectomy in other study (9).

There are reports to suggest adjuvant chemotherapy for ACC in the literature (10). However, there is no specific adjuvant chemotherapy recommendation for favorable histological subtypes of breast carcinoma including ACC cases. Besides, there has been no randomised clinical trials to guide changing adjuvant treatment of these better natured and uncommon histological subtypes of breast cancers.

ACC is a rare subtype of breast carcinomas with triple negative or basal-like features. They usually have an excellent outcome, however specific adjuvant treatment for this subtype of breast carcinoma is not standard yet because of lack of randomised controlled studies.

\section{Conflict of interest: None}

\section{References}

1. Sumpio BE, Jennings TA, Merino MJ, Sullivan PD. Adenoid cystic carcinoma of the breast: Data from the Connecticut tumor registry and a review of the literature. Ann Surg. 1987;205:295-301

2. Arpino G, Clark GM, Mohsin S, Bardou VJ, Elledge RM. Adenoid cystic carcinoma of the breast: molecular markers, treatment, and clinical outcome. Cancer 2002;94:2119-27

3. McClenathan JH, de la Roza G. Adenoid cystic breast cancer. Am J Surg 2002;183:646-9

4. Billroth T: Die Cylindergeschwalst. Untersuchungen ueber die Entwicklung der Blutgefefasse. Berlin: G Reimer; 1856:55-69

5. Page DL. Adenoid cystic carcinoma of breast, a special histopathologic type with excellent prognosis [comment]. Breast Cancer Res Treat 2005;93:189-90

6. Azoulay S, Lae M, Freneaux P, et al. KIT is highly expressed in adenoid cystic carcinoma of the breast, a basal-like carcinoma associated with a favorable outcome. Mod Pathol 2005;18:1623-31

7. Leeming R, Jenkins M, Mendelson G. Adenoid cystic carcinoma of the breast. Arch Surg 1992;127:233-5

8. Ro JY, Silva EG, Gallager HS. Adenoid cystic carcinoma of the breast. Hum Pathol 1987;18:127681

9. McClenathan JH, de la Roza G. Adenoid cystic breast cancer. Am J Surg. 2002;183:646-9

10. JH, Kim MJ, Kim EK, Lee JY, Oh KK, Park BW. Recurrence of adenoid cystic carcinoma in the breast after lumpectomy and adjuvant therapy. J Ultrasound Med 2006;25:921-4 